\title{
Vesetranszplantált beteg infrarenalis aortaaneurysmájának sikeresen kezelt esete
}

\author{
Boros Péter dr. - Olvasztó Sándor dr. - Litauszky Krisztina dr. \\ Bodnár Fruzsina dr. - Mészáros Júlia dr. - Tóth Csaba dr. \\ Debreceni Egyetem, Általános Orvostudományi Kar, Klinikai Központ, Sebészeti Klinika, \\ Érsebészeti Tanszék, Debrecen
}

\begin{abstract}
A hasi aortaaneurysmák kezelése vesetranszplantált betegek esetén összetett feladat. Az endovascularis aneurysmarekonstrukció (EVAR) elterjedésével, arra alkalmas esetekben, hatékony megoldást jelent transzplantációt követően is. Esettanulmányunkban vesetranszplantált beteg infrarenalis aortaaneurysmájának terápiáját prezentáljuk. 50 éves vesetranszplantált férfi beteg infrarenalis aortaaneurysmájának endovascularis ellátása közben fellépő technikai nehézség miatt konverzióra kényszerültünk. Nyitott mútét során az aorta kirekesztésének ideje alatt a transzplantált vese keringését extraanatomikus áthidalással biztosítottuk. Átmeneti vesefunkció-romlást követően a graftvese múködése évekig megfelelő volt. Saját esetünk kapcsán bemutatjuk az EVAR és a nyitott mútét nehézségeit, a graftvese funkciójának megőrzése érdekében alkalmazott módszereket. Áttekintjük a kapcsolódó szakirodalmat a transzplantált szerv ischaemiás károsodásának megelőzéséhez használható alternatívák tekintetében.
\end{abstract}

Orv Hetil. 2019; 160(37): 1471-1475.

Kulcsszavak: infrarenalis aortaaneurysma, endovascularis aneurysmarekonstrukció, vesetranszplantáció

\section{Successful treatment of infrarenal aortic aneurysm in the case of a patient after renal transplantation}

The management of the abdominal aortic aneurysm is associated with several risk factors, especially in patients after renal transplantation. Endovascular aneurysm repair (EVAR) can be the proper treatment in feasible cases. The authors present a patient's case who underwent renal transplantation and developed an infrarenal aortic aneurysm some years later. A 50-year-old male patient was operated with EVAR. During the starting period of the procedure bilateral iliac dissection developed, and the endovascular approach was converted into traditional open operation. At the time when the aorta was clamped, an extraanatomic shunt was applied to ensure the blood supply of the transplanted organ. In the early postoperative period, a transient renal function impairment was observed. Later on, the renal function returned to normal values. In this article, alternative methods used to prevent ischaemic damage of the transplanted organ during the procedure are presented as well. Finally, the authors report the international trends and experiences in the field of preserving the viability of a transplanted organ during abdominal aneurysm repairs.

Keywords: abdominal aortic aneurysm, endovascular aneurysm repair, renal transplantation

Boros P, Olvasztó S, Litauszky K, Bodnár F, Mészáros J, Tóth Cs. [Successful treatment of infrarenal aortic aneurysm in the case of a patient after renal transplantation]. Orv Hetil. 2019; 160(37): 1471-1475.

(Beérkezett: 2019. február 7.; elfogadva: 2019. április 7.)

\section{Rövidítések}

AFC = arteria femoralis communis; AIC = arteria iliaca communis; AIE $=$ arteria iliaca externa; AVF $=$ arteriovenosus fistu ${ }^{-}$ la; CIN $=$ (contrast-induced nephropathy) kontrasztanyag indukálta nephropathia; CTA = komputertomográfiás angio- gráfia; ESVS = (European Society for Vascular Surgery) Európai Érsebészeti Társaság; EVAR = (endovascular aneurysm repair) endovascularis aneurysmarekonstrukció; GFR = glomerulusfiltrációs ráta; $\mathrm{HD}=$ hemodialízis; IVUS = (intravascular ultrasound) intravascularis ultrahang; $\mathrm{UH}=$ ultrahang 
Abdominalis aortaaneurysmáról a hasi főverőér normálátmérőjének 1,5-szeres tágulatakor beszélünk [1]. Leggyakoribb lokalizációja az aorta infrarenalis szakasza. Fő rizikófaktorai az atherosclerosis, a hypertonia, a dohányzás, a kor és a férfinem [2]. Előfordulási gyakorisága fejlett országokban az 50 és 70 év közötti dohányos férfilakosság körében 5,9\% [3]. Legfontosabb, életet veszélyeztető szövődménye az aneurysma rupturája, melynek becsült rizikója 55 és 69 mm közötti átmérőjü tágulatok esetén évi 10\%, 70 mm fölötti átmérőnél azonban eléri a $33 \%$-ot $[3,4]$.

Nyitott mütéti megoldása vagy - arra alkalmas esetekben - endovascularis kezelése lehetséges $[1,2,4,5]$. Mütéti indikáció tünetmentes esetekben $5,5 \mathrm{~cm}$ fölötti aneurysmaátmérő esetén áll fenn, a ruptura valószínúsége ugyanis ezekben az esetekben haladja meg az elektív mütét perioperatív mortalitásának gyakoriságát $(2,7-$ $5,6 \%)$. Tünetes és rupturált esetekben a mütét abszolút indikált.

Veseelégtelenségben általánosan jellemző a szív-ér rendszeri kórfolyamatok gyakoribb előfordulása, ami a felgyorsult atherosclerosis következménye [6]. Az allograft-vesetranszplantáció a végstádiumú veseelégtelenség kezelésének jól ismert módszere, mely e betegek életkilátásait növeli. Az immunszuppresszáns gyógyszerek atherosclerosist fokozó hatása miatt a cardiovascularis események bekövetkeztének rizikója azonban a veseátültetést követően is emelkedett marad [7].

A transzplantációt követően kialakuló aortaaneurysmák gyakoriságáról kevés adat áll rendelkezésre. A közlemények többségében esettanulmányok formájában foglalkoznak a témával. Englesbe és mtsai 1557 beteg adatait elemezték: 296-an szív-, 450-en máj-és 811 -en veseátültetésben részesültek. Tanulmányukban az aortaaneurysmák gyakoriságát 4,1\%-ban állapították meg szívtranszplantált és 0,4\%-ban vese-, illetve májtranszplantáción átesett betegek körében [8].

$\mathrm{Az}$ alacsony elófordulási arány miatt a vesetranszplantációt követően kialakult hasi aortaaneurysmák ellátása egyéni terápiás tervek alapján valósítható meg.

Esettanulmányunkban egy 50 éves, vesetranszplantált férfi beteg kórtörténetén keresztül mutatjuk be a hasi aortaaneurysma kezelésének komplexitását.

\section{Esetismertetés}

A beteg anamnézisében 1980-ban tonsillopharyngitist követően kialakult akut glomerulonephritis, majd akut veseelégtelenség miatti kezelés található, melyet követően krónikus veseelégtelenség alakult ki. 1989-ben vesetranszplantáción esett át, a bal oldali fossa iliacába került beültetésre a graftvese. 1995-től krónikus rejectio miatt konzervatív kezelése kezdődött. Vesefunkcióinak romlása miatt 1996-ban a jobb csuklótájon Cimino-Bresciasönt kialakítása történt, majd 1999-től hemodialízisprogramba és transzplantációs várólistára került. 2000-ben ismételten vesetranszplantáció történt, a jobb oldalra került beültetésre a graftvese. Klinikánk transzplantációs szakrendelése gondozta, kontroll vesefunkciós paraméterei végig a normáltartományban voltak. 2007-ben transzplantációs szakrendelés által kért hasi UH-vizsgálat alkalmával $35 \mathrm{~mm}$ átmérőjü infrarenalis aortaaneurysma vált ismertté, mely miatt érsebészeti vizsgálat történt; rendszeres követést javasoltunk hasi UH formájában $[1,2,4,5]$. 2012-ben az aneurysma átmérője elérte az $55 \mathrm{~mm}$-t, melyet CTA-vizsgálat is igazolt. Érsebészeti véleményezés alapján sztentgraftbeültetést tartottunk indokoltnak, melynek elvégzésére más intézetben volt lehetôség. Az ajánlott beavatkozás ismeretlen okból nem történt meg. 2014-ben készült ismételten kontroll hasi UH transzplantációs szakrendelés kérésére. Ezen az aneurysma átmérője már meghaladta a 60 mm-t. CTA-felvételen az aneurysma átmérője 63,5 $\mathrm{mm}$ volt, és ráterjedt a bal oldali a. iliaca communisra (1. ábra), melynek átmérője $21,1 \mathrm{~mm}$ volt.

Elektív mútéti megoldást ajánlottunk. Preoperatív CTA alapján a páciens sztentgraft-implantációra alkalmasnak bizonyult, melynek intézetünkben való elvégzését betegünk elfogadta.

Alapos tervezés ellenére az EVAR kezdeti lépéseinél már nehézségekbe ütköztünk. A vezetődrótok felhelyezését követôen mindkét AIC-on dissectio jelentkezett, valamint a bal oldali AIC mellett extravasatum ábrázolódott. Technikai sikertelenség miatt konverzió mellett döntöttünk.

Medián laparotomiából feltártuk az infrarenalis aortaaneurysmát, az aorta és a két AIC kirekesztését követő-

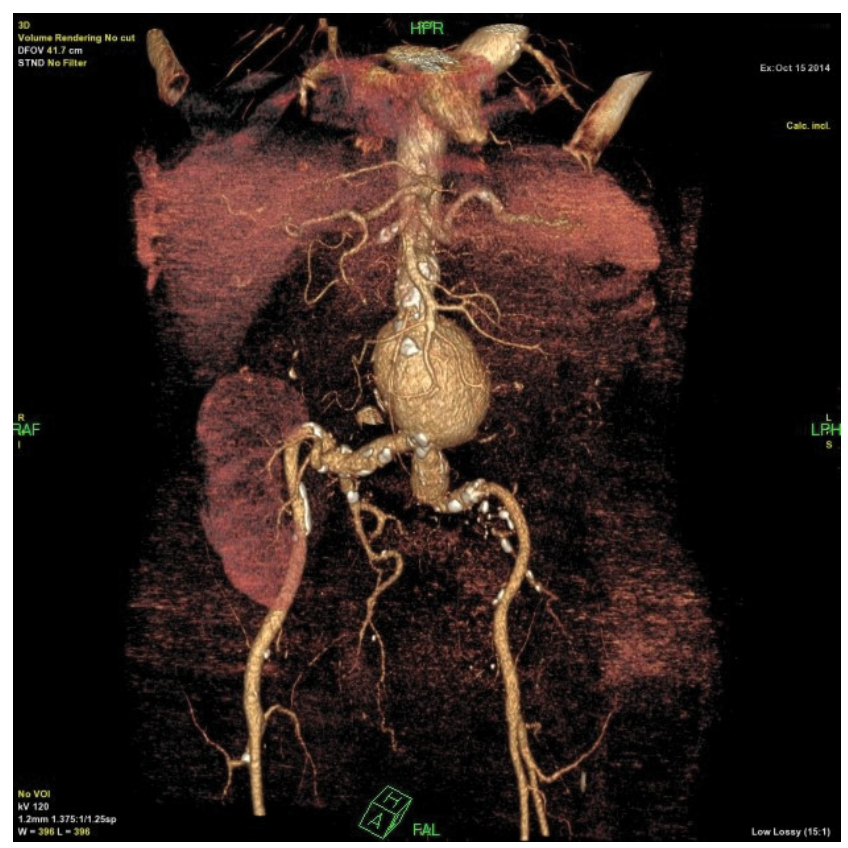

1. ábra

Preoperatív CTA-felvétel: infrarenalis aortaaneurysma; a bal AIC kezdeti szakaszának aneurysmaticus tágulata; transzplantált vese a jobb fossa iliacában

$\mathrm{AIC}=$ arteria iliaca communis; $\mathrm{CTA}=$ komputertomográfiás angiográfia 


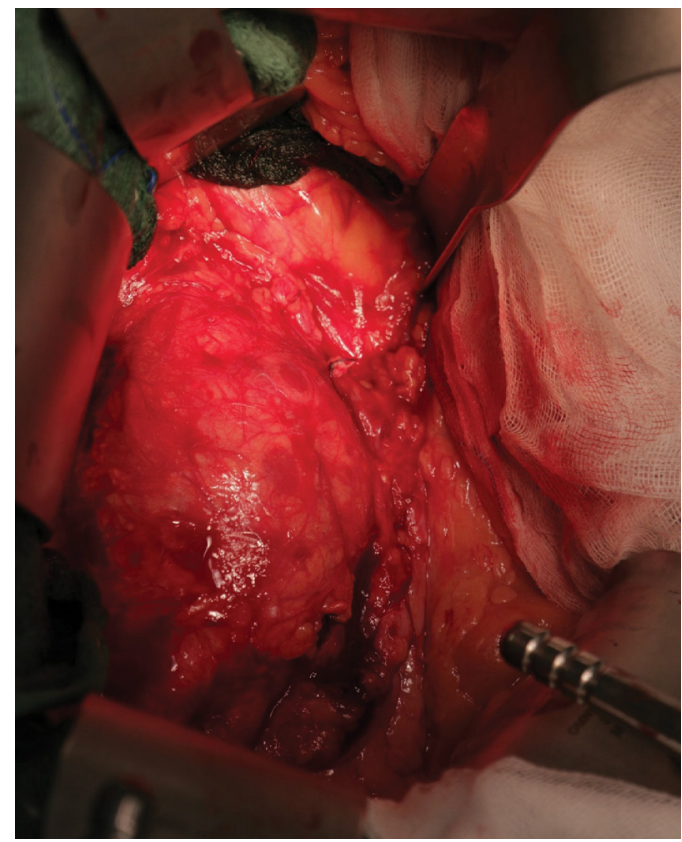

2. ábra

| Intraoperatív felvétel: az infrarenalis aortaaneurysma

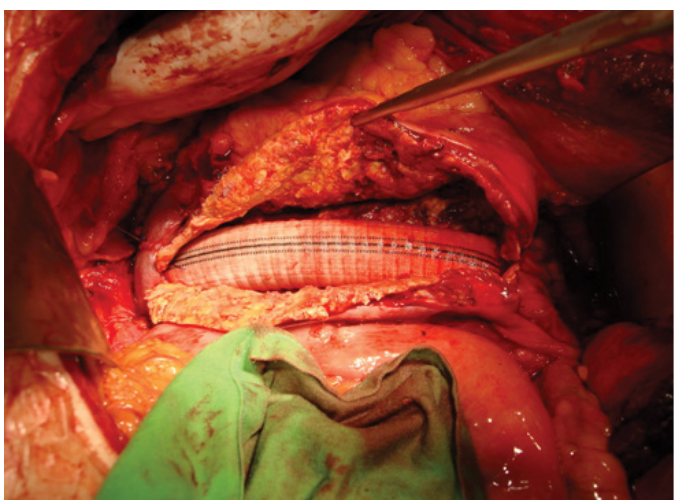

3. ábra

Intraoperatív felvétel: a rekonstrukció végén látható a dakronprotézis

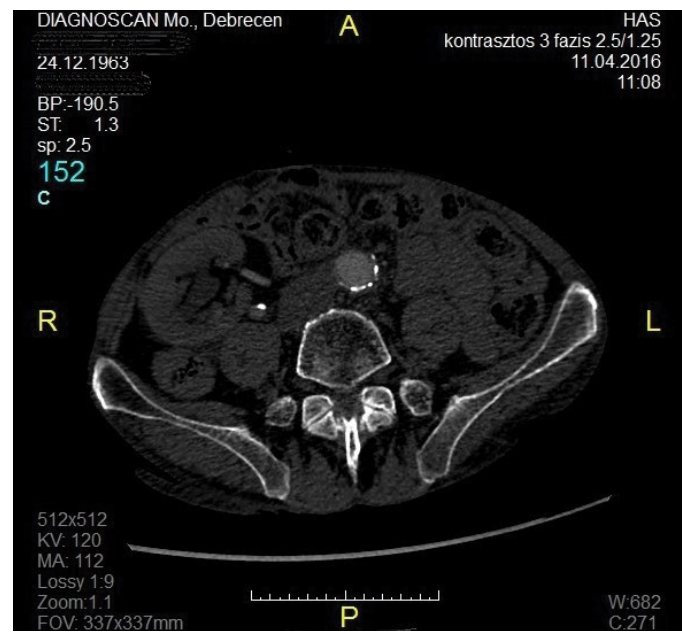

4. ábra

Kontroll-CTA-felvétel: pseudoaneurysma, graft körüli folyadékgyülem nem ábrázolódik. A transzplantált vese keringése megtartott

$\mathrm{CTA}=$ komputertomográfiás angiográfia en megnyitottuk az aneurysmazsákot, majd múér-interpositum felhasználásával rekonstruáltuk a keringést (2. és 3. ábra). Az aorta és az AIC-ok kirekesztése alatt egy extraanatomikus sönt segítségével retrográd úton biztosítottuk a transzplantált vese keringését: a jobb alkari múködő Cimino-fistula vénás szárát és a jobb oldali AFC-t infúziós szerelékkel kötöttük össze, így a Ciminofistula biztosította a jobb AFC-n, AIE-n keresztül a transzplantált vese perfúzióját. Az aorta és az AIC-ok átmérőjét figyelembe véve $6 \times 18 \mathrm{~mm}$-es dakronprotézis felhasználásával aortobiiliacalis interpositum került kialakításra. Az Y-graft proximalis és jobb oldali anastomosisát készítettük el először, ezzel is csökkentve a transzplantált szerv ischaemiás károsodásának veszélyét.

A mütét során Cell Savert alkalmazva $650 \mathrm{ml}$ saját vérrel és 3 egység vörösvértest-koncentrátummal transzfundáltuk a beteget, valamint hypotensio miatt keringéstámogatásra is szükség volt.

A korai posztoperatív szakban átmeneti légzés- és keringéstámogatást igényelt a beteg. Néhány órás anuriás időszak után vizelete is megindult, ennek ellenére salakanyagszintjei jelentősen megemelkedtek: a szérumkreatinin $536 \mu \mathrm{mol} / 1$, a szérumurea $34 \mathrm{mmol} / \mathrm{l}$ volt. A nefrológiai konzílium ischaemiás eredetű akut tubularis necrosist véleményezett, hemodialíziskezelést rendelt. 3 HD-kezelést követően a vesefunkciós értékek javulást mutattak. A későbbiekben nem volt szükség ismételt HD-kezelésre. Az érsebészeti kontroll során sebészi szövődményt nem észleltünk. A másfél évvel a mütétet követően hasi panaszok miatt készült kontroll-CTA-n a múérgraft és a transzplantált vese a. renalisa átjárható volt, álaneurysma-képződés nem ábrázolódott (4. ábra).

2016 második felében stroke következtében bal oldali hemiparesis alakult ki, majd 2016 decemberében a jobb oldali frontalis lebenyben elhelyezkedő tumor miatt idegsebészeti műtét történt. A szövettan diffúz nagy Bsejtes lymphomát igazolt.

Betegünk 2017 januárjában feküdt utoljára transzplantációs osztályunkon folyadék-, ionháztartás rendezése céljából. Vesefunkciós paraméterei a normáltartományban voltak: szérumkreatinin $97 \mu \mathrm{mol} / 1$, -urea 4,5 mmol/1, GFR $76 \mathrm{ml} / \mathrm{min} / 1,73 \mathrm{~m}^{2}$. A Hematológia Tanszékre történő átvételét követően 2017 februárjában betegünk elhunyt.

\section{Megbeszélés}

A vesetranszplantált betegeken végzett bármely mútéti beavatkozás - különösen a beültetett vese keringését befolyásoló beavatkozások - többletkockázatottal jár az egészséges vesemúködésű betegek eseteivel szemben. A hasi erek kirekesztése alatt a transzplantált vese potenciális ischaemiás károsodása következhet be, melynek elkerülésére törekednünk kell az operáció során. Az aortaaneurysma resectiós mútétei alatt a graftvese funkciójának megőrzési lehetőségeiről számos közlemény található az irodalomban. 
Sadat és mtsai összefoglalják az 1975-től 2008-ig közölt eseteket és azok tanulságait [9]. Az általunk alkalmazott eljáráshoz hasonló extraanatomikus ideiglenes söntöt használó technikákat már az 1970-es években is használtak. Átmeneti áthidalásokat alakítottak ki a mútét idejére extraluminalis pozícióban, vagyis kanülálták a kirekesztés fölötti aortaszegmenst és az AFC-t. A graftvese perfúzióját retrográd úton biztosították. Posztoperatív salakanyagszint-emelkedést nem tapasztaltak.

A transzplantált szerv védelme intraluminalis áthidalások alkalmazásával is biztosítható, amikor a mütét során a múérgraft lumenében helyezkedik el az átmeneti aortoiliacalis sönt, direkt módon biztosítva a transzplantált vese keringését [9].

A graftvese oldalán ideiglenesen kialakított axillofemoralis bypass használata szintén az 1970-80-as években volt gyakorlat, azonban Roach és mtsai a 2000-es évek elején is alkalmazták [10]. Az eljárás hosszabb mütéti időt jelentett, viszont a vesefunkció romlását elkerülték.

Több szerző előnyben részesíti a graftvédelem szempontjából a kirekesztési idő minimalizálását különböző kiegészítő technikák alkalmazása helyett. Gyorsan elkészített anastomosisokkal lerövidül a graftvese melegischaemiás ideje, csökken a posztoperatív funkcióvesztés veszélye. A közölt esetekben, mindössze néhány napig tartó posztoperatív kreatininszint-emelkedést észleltek $[10,11]$. Wablberg és munkacsoportja közleményében alátámasztja, hogy preoperatíve normál vesefunkciójú betegeknél, amennyiben az intraoperatív normotensio biztosított, és maximálisan 50 percig tartják fenn a suprarenalis aortakirekesztést, elkerülhető a posztoperatív vesekárosodás [12]. Saját esetünkben is törekedtünk a kirekesztési idő lerövidítésére.

Sadat és mtsai közleményükben összehasonlítva az allograftvédelem kiegészítő eszközöket használó stratégiáit a kirekesztési idő lecsökkentésére törekvő munkacsoportok eredményeivel, az utóbbi technika mellett foglaltak állást [9].

$\mathrm{Az}$ aortaaneurysmák endovascularis rekonstrukciójának elterjedésével adott a lehetőség multimorbid betegek aneurysmáinak minimálinvazív megoldására. Az EVAR előnyei közé tartozik a hagyományos műtéti megoldásnál gyorsabb felépülés rövidebb kórházi tartózkodás mellett, hogy az aorta nem kerül kirekesztésre. Vesetranszplantált beteg aortaaneurysmájának EVARtechnikával történő kezeléséról a 2000-es évek elején jelentek meg először közlemények. Sahwney és mtsai aortomonoiliacalis sztentgraftrendszert alkalmaztak, melynek felvezetése a transzplantált vese ischaemiás károsodásának elkerülése céljából az ellenoldali AFC-n, AIE-n keresztül történt. A graftveseoldali AIC-t occluderrel zárták, majd az adott oldali végtag és a transzplantált szerv keringését femorofemoralis crossover bypass kialakításával biztosították [13]. Ezt követően egyre több munkacsoport alkalmazott sikerrel aortobiiliacalis sztentgraftrendszereket vesetranszplantált betegek ese- tén is [14-16]. Többéves utánkövetéses vizsgálatok során sem észleltek komolyabb eltérést a beültetett vese múködésében [16]. Karkos és mtsai sikeresen alkalmaztak EVAR-technikát vesetranszplantált betegen, akinél egy korábbi aortaaneurysma megoldásaként beültetett aortoaorticus interpositum distalis anastomosisa helyén kialakult álaneurysma miatt volt szükség rekonstrukciós mútétre. Anatómiai okokból a sztentgraft felvezetése a graftveseoldali iliacarendszeren keresztül történt. Egy hónapos color Doppler-kontrollvizsgálaton észlelték a transzplantált vese oldalán lévő graftszár distalis szakaszának stenosisát. Angiográfia során felismerésre került továbbá az azonos oldali AIC dissectiója is, melynek megoldása sztentimplantációval történt [17].

Számos eredményes eset mellett figyelembe kell venni az EVAR során felmerülő technikai nehézségeket, különösen vesetranszplantált betegek kezelésekor. A graftrendszer felvezetése anatómiai alkalmasság esetén a beültetett szervhez viszonyítva ellenoldali iliacalis ereken keresztül biztonságosabbnak tekinthető, mind aortomonoiliacalis, mind biiliacalis graftok alkalmazása esetén. Biiliacalis graftoknál a modularis részt - a kiegészítő ellenoldali iliacalis graftszár - felvezető eszköz átmérője keskenyebb a fótestnél, így annak felvezetése a transzplantált szerv oldalán kisebb valószínűséggel okozza a szerv ellátó artériájának occlusióját, sérülését. A biiliacalis rendszerek alkalmazása előnyösebb a transzplantált szerv artériás perfúziója szempontjából, mivel azt anterográd úton biztosítja. Megfelelő tervezés és gyakorlat szükséges, hogy elkerüljük a thrombust tartalmazó aneurysmazsákból eredő esetleges embolisatiót is. Növeli az ischaemiás károsodás veszélyét az esetleges korai szövődmények, endoleakek ellátása is $[1,2,4,5]$.

Az endovascularis aneurysmarekonstrukciók elengedhetetlen része az angiográfiás kontroll, mely magában hordozza a kontrasztanyag indukálta nephropathia kialakulásának veszélyét. A CIN prevalenciája 0,5-2,3\% az átlagpopulációban, az idősebb korosztályban azonban, diabeteses, veseelégtelen, szívelégtelen betegeken, gyakoribb előfordulású [1]. Megelőzésének módjáról számos közlemény található az irodalomban [2, 4, 18-20]. Az ESVS 2010-es ajánlása alapján elsődleges a megfelelő hidrált állapot biztosítása izotóniás $\mathrm{NaCl}$-oldat $1 \mathrm{ml}$ / ttkg/óra infúzióval a beavatkozás napján [1]. Okuma és mtsai a CIN megelőzése céljából infúzió mellett per os $\mathrm{N}$-acetil-ciszteint használtak az EVAR-t megelőző napon és a mütét napján. A felhasznált kontrasztanyag mennyiségének csökkentéséhez a mütét végén kontrollangiográfia helyett color Doppler-vizsgálattal ellenőrizték, hogy kialakult-e endoleak [18].

A kontrasztanyag mennyiségének minimalizálására további lehetőség a $\mathrm{CO}_{2}$-angiográfia. Chao és mtsai EVAR során használt a $\mathrm{CO}_{2}$-angiográfiával és a hagyományos jód izotópot tartalmazó angiográfiával szerzett tapasztalataikat hasonlították össze. $\mathrm{CO}_{2}$-angiográfiát alkalmaztak veseelégtelen betegek mütéteinél. Posztoperatív vesefunkció-romlást nem tapasztaltak egyik csoportban 
sem. A $\mathrm{CO}_{2}$-angiográfia kapcsán a gáz gyors intravascularis eliminációja miatt hosszabb mútéti időről számoltak be, mely megnövekedett sugárterhelést is jelentett [19].

$\mathrm{Az}$ intravascularis ultrahang (IVUS) használata endovascularis beavatkozások alatt tovább csökkentheti a nephrotoxicus kontrasztanyag használatát. Hoshina és $m$ tsai közleményükben kiemelik az IVUS előnyeit, különösen az a. renalisok és a. iliaca internák eredéseinek lokalizációjában. Jódot tartalmazó kontrasztanyaggal végzett angiográfiára mindössze a mútét végén van szükség az endoleakek kizárásához [20].

\section{Következtetés}

A vesetranszplantált betegek hasi aortaaneurysmáinak ellátása összetett feladat. Rekonstrukciós mütétek során a transzplantált szerv funkciójának védelme, ischaemiás károsodásának megelózése alapvető jelentőségú. A beteg általános állapotát, anatómiai adottságait figyelembe véve endovascularis és hagyományos, nyitott helyreállító mútéti megoldások közül választhatunk. Vesetranszplantált beteg aortaaneurysmájának EVAR-ral történő kezelése megfelelő beteg-előkészítéssel, a kontrasztanyag-felhasználás minimalizálásával a vesefunkciót nem rontja. A nyitott aneurysmamútétek alatt alkalmazható számos kiegészítő technika közül az általunk használt áthidalás biztonságos módszernek bizonyult, feltétele azonban a múködő AVF. Figyelembe kell venni, hogy a kis esetszám miatt a rekonstrukció, valamint a graftvédelem módja egyéni mérlegelést igényel.

Anyagi támogatás: A közlemény megírása anyagi támogatásban nem részesült.

Szerzői munkamegosztás: B. P.: A kézirat megírása, mútéti asszisztencia, irodalomgyújtés és interpretálás. T. Cs.: A beteg érsebészeti gondozása, a mútét elvégzése, a kézirat áttekintése, javítása. B. F., O. S., L. K., M. J.: A kézirat áttekintése, javítása. A cikk végleges változatát valamennyi szerző elolvasta és jóváhagyta.

Érdekeltségek: A szerző́knek nincsenek érdekeltségeik.

\section{Irodalom}

[1] Moll FL, Powell JT, Fraedrich G, et al. Management of abdominal aortic aneurysms clinical practice guidelines of the European Society for Vascular Surgery. Eur J Vasc Endvasc Surg. 2011; 41(Suppl 1): S1-S58.

[2] Chaikof EL, Brewster DC, Dalman RL, et al. The care of patients with abdominal aortic aneurysm: The Society for Vascular Surgery practice guidelines. J Vasc Surg. 2009; 50(4 Suppl): S2S49.
[3] Lederle FA, Johnson GR, Wilson SE, et al. The aneurysm detection and management study screening program: validation cohort and final results. Arch Intern Med. 2000; 160: 1425-1430.

[4] Chaikof EL, Dalman RL, Eskandari MK, et al. The Society of Vascular Surgery practical guidelines on the care of patient with abdominal aortic aneurysm. J Vasc Surg. 2018; 67: 2-77.e2.

[5] Erbel R, Aboyans V, Boileau C, et al. 2014 ESC guidelines on the diagnosis and treatment of aortic diseases: Document covering acute and chronic aortic diseases of the thoracic and abdominal aorta of the adult. The Task Force for the Diagnosis and Treatment of Aortic Diseases of the European Society of Cardiology (ESC). Eur Heart J. 2014; 35: 2873-2926. Erratum: Eur Heart J. 2015; 36: 2779.

[6] P Szabó R, Varga I, Balla J, et al. Cardiovascular screening and management among kidney transplant candidates in Hungary. Transplant Proc. 2015; 47: 2192-2195.

[7] Ojo OA. Cardiovascular complications after renal transplantation and their prevention. Transplantation 2006; 82: 603-611.

[8] Englesbe MJ, Wu AH, Clowes AW, et al. The prevalence and natural history of aortic aneurysm in heart and abdominal organ patients. J Vasc Surg. 2003; 37: 27-31.

[9] Sadat U, Huguet EL, Varty K. Abdominal aortic aneurysm surgery in renal, cardiac and hepatic transplant recipients. Eur J Vasc Endovasc Surg. 2010; 40: 443-449.

[10] Roach DM, Thompson MM, Patrick GM, et al. Aortic aneurysm repair with a functioning renal transplant: therapeutic options. ANZ J Surg. 2004; 74: 65-67.

[11] Moon IS, Park SC, Kim SN, et al. Abdominal aortic aneurysm repair in kidney transplant recipients. Transplant Proc. 2006; 38: 2022-2024.

[12] Wahlberg E, DiMuzio PJ, Stoney RJ. Aortic clamping during elective operations for infrarenal disease: the influence of clamping time on renal function. J Vasc Surg. 2002; 36: 13-18.

[13] Sahwney R, Chuter TA, Wall SD, et al. Aortic stent-grafts in patients with renal transplants. J Endovasc Ther. 2000; 7: 286291.

[14] Abad C, Maynar M, De Blas M, et al. Endovascular repair of abdominal aortic aneurysm in a renal transplant patient. J Cardiovasc Surg. 2000; 41: 915-917.

[15] Forbes TL, DeRose G, Kribs S, et al. Endovascular repair of abdominal aortic aneurysm with coexisting renal allograft: case report and literature review. Ann Vasc Surg. 2001; 15: 586-590.

[16] Khanmoradi K, Brewster DC, Haddad FF, et al. Endovascular repair of abdominal aortic aneurysm in a kidney transplant patient with 4-year follow-up. Surgery 2004; 136: 103.

[17] Karkos CD, McMahon G, Fishwick G, et al. Endovascular abdominal aortic aneurysm repair in the presence of a kidney transplant: therapeutic considerations. Cardiovasc Intervent Radiol. 2006; 29: 284-288.

[18] Okuma S, Fujii T, Sasaki Y, et al. Endovascular abdominal aortic aneurysm repair in patients with renal transplants: reports of two cases. Ann Thorac Cardiovasc Surg. 2014; 20(Suppl): 809-812.

[19] Chao A, Major K, Kumar SR, et al. Carbon dioxide digital subtraction angiography-assisted endovascular aortic aneurysm repair in the azotemic patient. J Vasc Surg. 2007; 45: 451-458.

[20] Hoshina K, Kato M, Miyahara T, et al. A retrospective study of intravascular ultrasound use in patients undergoing endovascular aneurysm repair: its usefulness and a description of the procedure. Eur J Vasc Endovasc Surg. 2010; 40: 559-563.

(Boros Péter dr., Debrecen, Móricz Zs. krt. 22., 4032 e-mail: boros.peterdr@gmail.com

A cikk a Creative Commons Attribution 4.0 International License (https://creativecommons.org/licenses/by/4.0/) feltételei szerint publikált Open Access közlemény,

melynek szellemében a cikk bármilyen médiumban szabadon felhasználható, megosztható és újraközölhető, feltéve, hogy az eredeti szerző és a közlés helye, illetve a CC License linkje és az esetlegesen végrehajtott módosítások feltüntetésre kerülnek. (SID_1) 